Www.jmscr.igmpublication.org

Impact Factor (SJIF): 6.379

Index Copernicus Value: 79.54

ISSN (e)-2347-176x ISSN (p) 2455-0450

crossrefDOI: https://dx.doi.org/10.18535/jmscr/v6i10.153

\title{
Functional Outcome of Distal Tibial Fractures Managed with Distal Tibial Locking Plate Using MIPPO Technique
}

\author{
Authors \\ Dr Rajan Sharma M.S Orthopaedics ${ }^{1}$, Dr Simranjit Singh, M.S. Orthopaedics ${ }^{2 *}$ \\ ${ }^{1}$ Associate Professor, Sri Guru Ram Das Institute of Medical Sciences and Research, Vallah, Amritsar \\ ${ }^{2}$ Senior Resident, Govt. Medical College, Amritsar \\ *Corresponding Author
}

Dr Simranjit Singh, M.S. Orthopaedics

Senior Resident, Govt. Medical College, Amritsar

House no. 22, street no. 2, Gopal nagar, Majitha road, Amritsar, Pin 143001, India

Mobile no.:-+919814670083

\begin{abstract}
Tibia is the most commonly fractured bone amongst all long bones of the body due to its position and lack of soft tissue protection. A variety of treatment methods have been suggested for these injuries, including non operative treatment, external fixation, intramedullary nailing and plate fixation. 25 patients with fracture of distal tibia were included in the study, Fractures were reduced by principle of ligamentotaxis and using MIPPO technique and fixed with distal tibial locking plate and functional outcome was analysed with AOFAS ankle and hind foot score. All fractures showed union upto 24 weeks and 20 patients had AOFAS score between 71-100 at 6 months.

Keywords: MIPPO, distal tibia locking plate, distal tibia fractures.
\end{abstract}

\section{Introduction}

Due to its subcutaneous nature and lackof adequate musculature, fracture of tibia is quite common. Tibial shaft fractures are caused by either direct violence (as in motor vehicle accidents), or indirect stress (Falls with the foot fixed). Direct violence accounts for an increasing number of tibial fractures. Depending on the fracture pattern, level, and soft tissue damage of the tibia, various methods of management have been described. The key to manage these troublesome fractures is to skilfully preserve and reconstruct the soft tissues, satisfactory reduction and alignment of the fracture, and early mobilization. Tibia is the most commonly fractured bone amongst all long bones of the body due to its position and lack of soft tissue protection $^{[1]}$. A variety of treatment methods have been suggested for these injuries, including non operative treatment, external fixation, intramedullary nailing and plate fixation ${ }^{[2]}$.

\section{Material and Methods}

Our study was conducted with the aim to evaluate management of distal tibial fractures using distal tibial locking plate using Minimally invasive percutaneous plate osteosynthesis technique (MIPPO) with special reference to fracture union 
in good alignment and functional outcome of patients. 25 patients with fracture of distal tibia were included in the study

\section{Inclusion criteria}

1. All extra articular and intraarticular closed fractures of distal 1/3 Tibia

2. Patients aged more than 18 years

\section{Exclusion criteria}

1. Open fractures where soft tissue cover to the implant is not possible.

2. Previous or existing infection in the involved leg.

The patients were first seen in the casualty. The history was taken followed by general and local examination of the patient. Neurovascular status was noted specially for nerve injury. $X$ rays and other investigation were done. The fracture was temporarily immobilized with a below knee slab. Preoperative planning and investigations were done, Fractures were classified according to AO Classification and the patients were posted for distal tibial locking plate fixation after subsidence of swelling. The patients were followed up every four weeks till radiological union was seen. At every follow up clinical examination was done to assess status of the surgical wound, pain, tenderness, range of motion of ankle, stability of the fracture and clinical union. $\mathrm{X}$ rays were taken in AP and Lateral views to look for signs of radiological union. The union was confirmed radiologically when plain X-ray showed bone trabeculae or cortical bone crossing fracture site on at least three surfaces .Postoperative X-rays was done to document proper reduction and fixation of fracture fragments. Ankle mobilization and knee flexion was started as early as possible depending upon condition of patient and level of fixation. Antibiotics (Intravenous/Oral) continued till the wound condition necessitated.

\section{Operative procedure}

Under spinal/general anaesthesia, the patient was placed supine on operation table. Under all aseptic conditions, after proper painting and draping and under $\mathrm{C}$-Arm image intensifier control, Fracture was reduced by principle of ligament taxis and using MIPPO technique, fixed with distal tibial locking plate after inserting it retrograde epiperiosteal between bone and intact soft tissue. In case of intraarticular fractures, accurate reduction was confirmed and provisional fixation was done with $\mathrm{K}$ wires or screws before proceeding with plate fixation.

Table 1 Age Distribution

\begin{tabular}{|l|c|c|}
\hline Age In Years & Number of Patients & Percentage \\
\hline $19-35$ & 8 & $32 \%$ \\
\hline $35-50$ & 7 & $28 \%$ \\
\hline$>50$ & 10 & $40 \%$ \\
\hline
\end{tabular}

Table 2 Mode of Injury

\begin{tabular}{|l|c|c|}
\hline Mode of Injury & No. of Patients & Percentage \\
\hline RTA & 17 & $68 \%$ \\
\hline Fall & 8 & $32 \%$ \\
\hline
\end{tabular}

Table 3 Distribution According to Type of Fracture-AO Classification

\begin{tabular}{|l|c|c|}
\hline Type of Fracture & No of patients & Percentage \\
\hline Extra articular(type a) & 10 & $40 \%$ \\
\hline $\begin{array}{l}\text { Partial articular } \\
\text { type b) }\end{array}$ & 10 & $40 \%$ \\
\hline $\begin{array}{l}\text { Complete } \\
\text { articular(type c) }\end{array}$ & 5 & $20 \%$ \\
\hline
\end{tabular}

Table 4 Distribution of Subjects According to Time to Bony Union (Radiological)

\begin{tabular}{|l|c|c|}
\hline Time & No. of Patients & Percentage \\
\hline By 16 weeks & 2 & $8 \%$ \\
\hline By 20 weeks & 18 & $72 \%$ \\
\hline By 24 weeks & 5 & $20 \%$ \\
\hline
\end{tabular}

Table 5 Distribution of Patients According to Total AOFAS Score

\begin{tabular}{|l|c|c|c|}
\hline Score & 1 month & 3 months & 6 months \\
\hline $\mathbf{0 - 3 0}$ & 10 & 3 & 0 \\
\hline $\mathbf{3 1 - 7 0}$ & 15 & 18 & 5 \\
\hline $\mathbf{7 1 - 1 0 0}$ & 0 & 4 & 20 \\
\hline
\end{tabular}






Case 1 Pre and Post Operative X-Rays

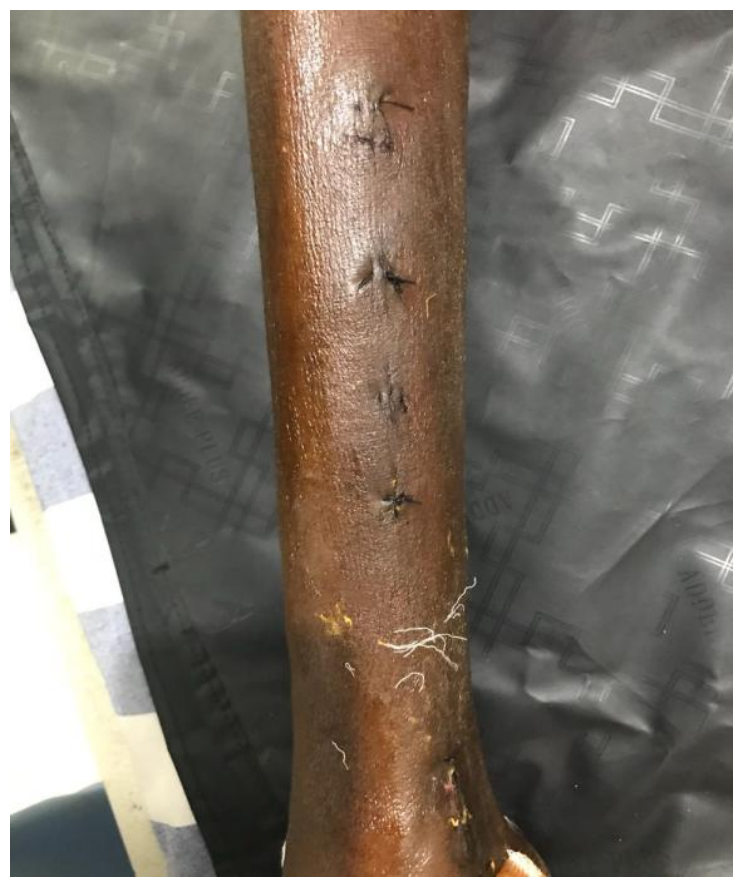

Case 1 Postoperative Skin Condition at 2 Weeks of Surgery
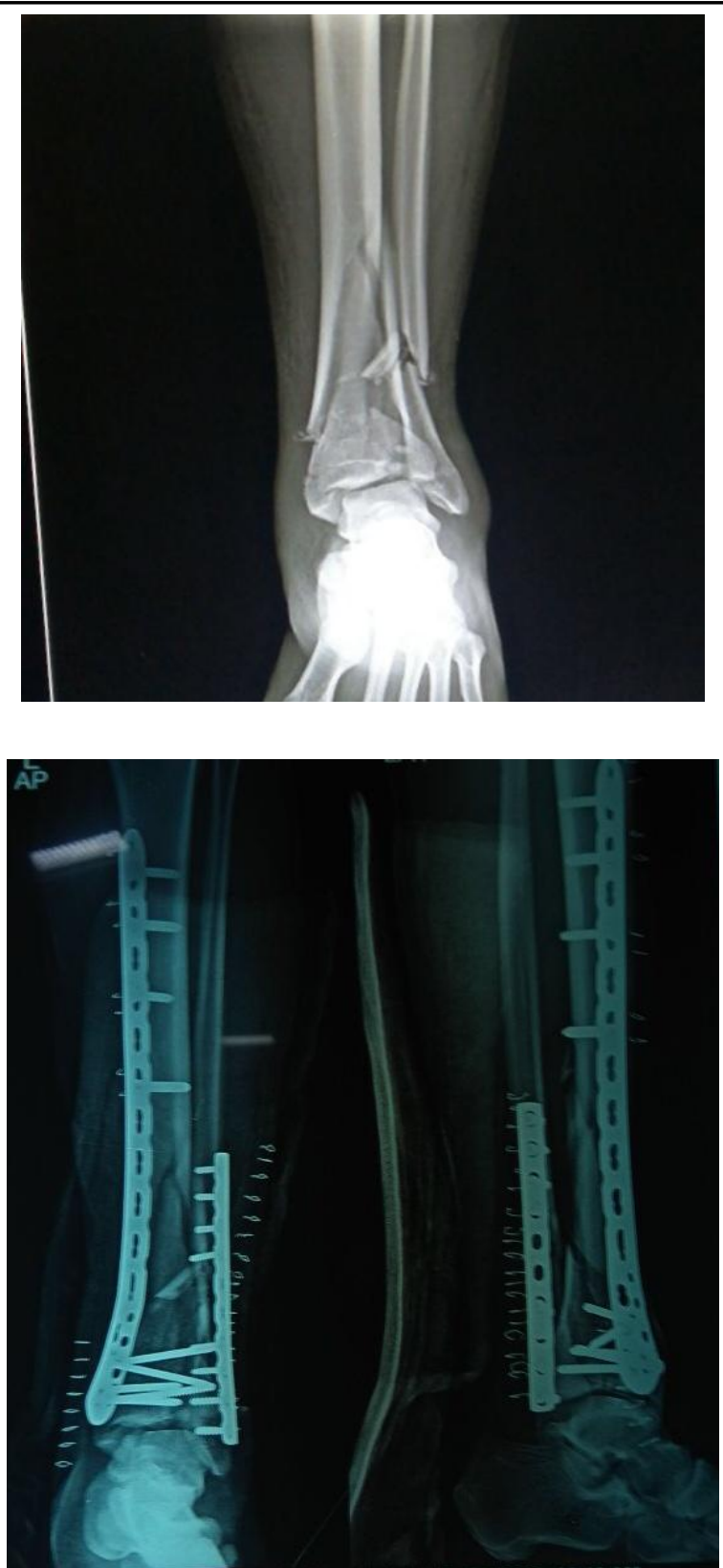

Case 2 Pre and Postoperative X-Rays

\section{Discussion}

Distal metaphyseal fractures are challenging fractures to treat given the number of complications arising out of various surgical modalities of treatment. These fractures are most often high energy fractures resulting from axial and rotational force on distal tibia ${ }^{[4-7]}$. The bridging principle is typically represented by the concept of minimally invasive percutaneous plate fixation (MIPPO technique), whereby the angular stable plate is used as an internal splint that bridges the comminuted fracture. With this method, indirect reduction is performed by ensuring adequate axial alignment, length and 
rotation of the extremity while the fracture fragments are not exposed or directly reduced. The bridging concept provides relative elastic fixation that promotes secondary fracture healing and callus formation. Fractures were classified according to AO classification and functional outcome was analysed with AOFAS ankle and hindfoot score. In our study of 25 cases, 20 patients $(80 \%)$ were males and 5 patients $(20 \%)$ were females. All the fractures showed union upto 24 weeks after surgery. AOFAS score was calculated using three parameters that is pain, function and alignment. At 6 months, 20 patients had score 71-100 and 5 patients had score 3170 .Out of 25 cases, 2 patients achieved union at 16 weeks, 18 patients at 20 weeks and 5 patients achieved union at 24 weeks. Superficial infection was noted in 2 patients which subsided with antibiotics in seven days. Persistent pain was noted in 1 case and no case of malunion or shortening was observed.

\section{Conclusion}

We conclude from our study that distal tibial locking plate is very effective in the management of distal tibial fracture using MIPPO technique provided proper patient selection is done and all the key principles are followed.

\section{References}

1. Paige W. Fracture of lower extremity: tibia pilon fracture. In: Terry C. James B (eds) Campbell's operative orthopaedics, eleventh edition, Philadelphia: Mosby Elsevier. 2010; 3118-19

2. Boris Zelle A, Mohit Bhandari, Michael Espiritu. Treatment of Distal Tibia Fractures without Articular Involvement: A Systematic Review of 1125 Fractures. J Orthop Trauma. 2006; 20:76-79.

3. Newman SD, Mauffey CP, Krikler S. Distal metaphyseal tibial fractures. Injury. 2011; 42:975- 84.

4. Richard RD, Kubiak E, Horwirtz DS. Techniques of surgical treatment of distal tibial fractures. Orthop Clin North Am. 2014; 45:295-312.

5. Bedi A, Le TT, Karunakar MA. Surgical treatment of nonarticular distal tibia fractures. J Am Acad Orthop Surg. 2006; 14:406-16.

6. Vallier HA, Cureton BA, Patterson BM. Factors influencing functional outcomes after distal tibia shaft fractures. J Orthop Trauma. 2012; 26:178-83. 8. 